\title{
Comparison Study on the Coseismic Deformation of the 1999 Chi-Chi Earthquake and Long-term Stream Gradient Changes Along the Chelungpu Fault in Central Taiwan
}

\author{
Quocheng Sung ${ }^{1, *}$, Yen-Che Chen ${ }^{2}$, Hen Tsai ${ }^{3}$, Yue-Gau Chen ${ }^{4}$, Wen-Shan Chen ${ }^{4}$
}

(Manuscript received 28 February 2000, in final form 6 July 2000)

\begin{abstract}
The largest inland earthquake ( $M_{L}=7.3$ ) of the 20th century in Taiwan occurred at $0147 \mathrm{hrs}$ local time on 21 September, 1999 near the small town of Chi-Chi, in central Taiwan. The crustal deformation pattern, caused by the Ch-Chi earthquake, appears to be unrelated to the velocity field that GPS stations measured in the period 1992 to 1995 . It exhibits a greater horizontal and vertical slip in the northern block between the Tachia River and the Wu River than in the southern block between the Wu River and the Tzoshui River. This study compares the stream profiles of three rivers in central Taiwan, namely the Tachia, Wu and Tzoshui Rivers, which run westward across the Shuilikeng fault, the Shuangtung fault, the Chelungpu fault and the Changhwa fault. Historical change of stream gradient is retrieved by a comparison of previous maps published by the Japanese authorities in 1904 and produced by the Department of Interior, ROC in 1985. The results, simulated by the diffusion model, indicate that the changes are attributable to the crustal movement in this area over the past 80 years. It is concluded that crustal deformation has been more evident in the block between the Tachia River and the Wu River than that between the $\mathrm{Wu}$ River and the Tzoshui River. This result agrees with the faulting net slip caused by the Chi-Chi earthquake. The method used in this study has been verified as a feasible tool in the research of earthquake prediction and seismic hazard assessment. Further studies are necessary in such a tectonically active area as Taiwan.
\end{abstract}

(Keywords: Chi-Chi earthquake, Crustal deformation, SL Index, Active fault)

\footnotetext{
${ }^{1}$ Department of Geography, National Kaohsiung Normal University, Taiwan

${ }^{2}$ Department of Earth Sciences, National Cheng Kung University, Taiwan

${ }^{3}$ Department of Geography, National Changhua University of Education, Taiwan

${ }^{4}$ Department of Geology, National Taiwan University, Taiwan

${ }^{*}$ Corresponding author address: Prof. Quocheng Sung, Dept. of Geography, National Kaohsiung Normal Univ. 116 Ho-Ping 1st Rd., Kaohsiung 802, Taiwan, ROC

E-mail: sungqc@nknucc.nknu.edu.tw
} 


\section{INTRODUCTION}

The Taiwan orogenic belt was formed by an arc-continent collision that occurred after the late Miocene (Ho 1988; Teng 1987, 1990). It can be divided into several geologic terrains. From east to west, they are the Coastal Range, Central Range, Western Foothills and Coastal Plain. In central Taiwan the Western Foothills consists of a series of subparallel thrust faults and related folds, which construct the western part of the fold and thrust belt of thin-skinned deformation (Suppe 1981, 1983). In this district, most of the active folding and thrusting which took place is associated with east-dipping reverse faults, namely the Shuilikeng, Shuangtung, Chelungpu, and Changhwa faults. The Chelungpu fault is the western boundary of the foothills. It is an overthrust, showing a hanging wall of Pliocene deformed strata riding upon a footwall of late Quaternary sequence and recent alluvium (Chang 1971; CPC 1982a, b; Chang et al. 1998). Over the past one hundred years, this area has experienced coseismic surface rupturing several times, in $1906\left(M_{L}=7.1\right)$ and $1935\left(M_{L}=7.1\right)(C h e n g$ et al. 1999).

The largest inland earthquake $\left(M_{L}=7.3\right)$ of the 20th century in Taiwan occurred at $0147 \mathrm{hrs}$ local time near a small town, Chi-Chi, in central Taiwan on 21 September, 1999. The epicenter was located at $23.85^{\circ} \mathrm{N}, 120.81^{\circ} \mathrm{E}$, and the depth of the hypocenter was about 7 to $10 \mathrm{~km}$. According to investigations reported by the Central Geological Survey (CGS), Ministry of Economic Affairs, a continuous surface rupture extending for about $100 \mathrm{~km}$ along the Chelungpu fault has been found with vertical thrust and left-lateral strike-slip offset. From its southern end due east of Taichung city the rupture closely follows the N-S trending preexisting Chelungpu fault trace. However, to the north, the newly formed rupture runs along the borderline of the foothills instead of the preexisting Chelungpu fault trace. Farther to its northern end, it curves toward the northeast and ramifies into complex branches which extend northeast for over 15 $\mathrm{km}$ and have never been previously identified as active faults (Fig.1).

GPS geodetic measurements taken after the Chi-Chi earthquake showed a striking crustal deformation along the upthrown block of the 1999 rupture (CGS 1999). In general, the vertical displacement of this fault exhibits an average of $2 \sim 3 \mathrm{~m}$ in the south and reaches a maximum slip of 7 8 $\mathrm{m}$ in the north (Ma et al. 1999, Bilham and Yu 2000). There is a greater horizontal and vertical slip in the northern block between the Tachia River and the Wu River than in the southern block between the Wu River and the Tzoshui River (CGS 1999). The crustal deformation pattern induced by the Chi-Chi earthquake seems to be unrelated to the velocity field for GPS stations monitored in the period of 1990 to 1995(Fig. 2); these stations showed much smaller velocity vectors in central Taiwan than in southern and eastern Taiwan (Yu et al. 1997). This was probably resulted from the distribution of GPS stations being too sparse and the measurement interval too short to obtain the entire picture of crustal deformation along the Chelungpu fault. We therefore propose that a comparison study of topographic features can be made between a historical map of 1904 and a more recent map to disclose features of crustal deformation over a longer period of time.

Based on two historical maps, we compare the longitudinal profiles along three major rivers in central Taiwan, namely the Tachia, Wu and Tzoshui, which run westwards through the Shuilikeng, Shuangtung, Chelungpu and Changhwa faults. One of the above-mentioned maps is the 1904 version of Taiwan Bautu on a scale of $1 / 20000$, which was mapped by the 


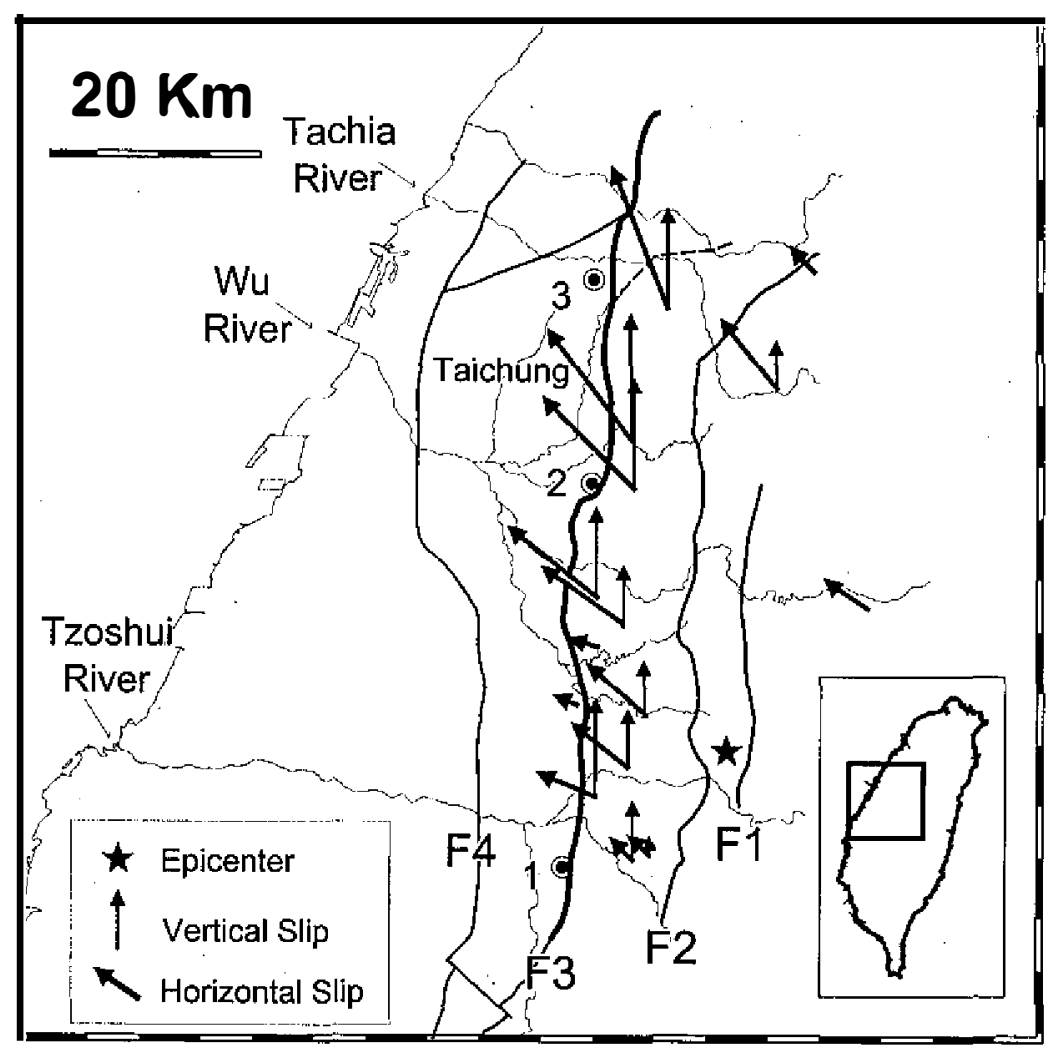

Fig. l. Permanent deformation after the Chichi earthquake, measured by the GPS stations along the Chelungpu fault (CGS 1999). Solid lines are active faults, namely Shuilikeng fault (F1), Shuangtung fault (F2), Chelungpu fault (F3), and Changhwa fault (F4). Dash line is surface rupture of the Chichi fault. The maximum horizontal and vertical slip is $8.5 \mathrm{~m}$ and $3.4 \mathrm{~m}$ respectively. Numerals denote localities: 1 . Chushan, 2. Chienming bridge, 3 . Fengyuan.

Japanese authorities in Taiwan. The other is a 1985 version topographic map on a scale of $1 /$ 25000 , which was published by the Department of Interior, ROC Stream gradient change over the period of 80 years is statistically verified and is also simulated by the diffusion model under the assumption of crustal movement. It is hoped that this study will lead to a better understanding of deformation and related mechanisms in the Chi-Chi earthquake.

\section{THEORETICAL BACKGROUND}

The longitudinal profile of a river represents its gradient at each given point as a reaction to tectonic, lithologic and climatic factors. The gradient in the upper reach is steeper, decreas- 


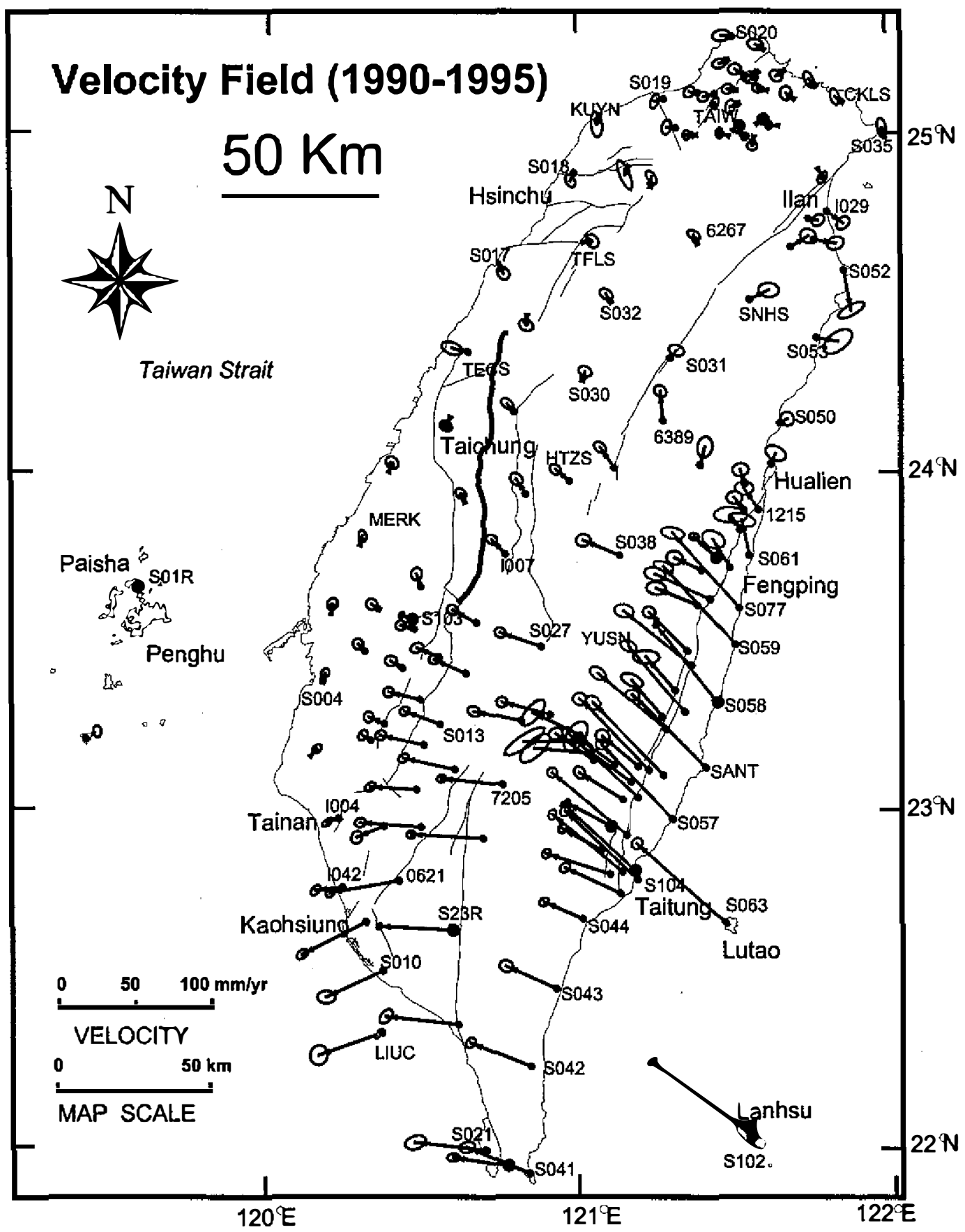

Fig. 2. Velocity field with respect to the Penghu station monitored by the GPS Network (Yu et al. 1997). Thin lines are active faults. Crustal deformation is indistinct along the Chelungpu fault (the heavy line). 
ing gradually, and is very low in the delta reach, dwindling to zero at sea level. This profile results in a concave-upward curve that is composed of segments, each of which can be mathematically defined (Tanner 1971). A number of previous studies with respect to active crustal warping provide useful information related to river profile adjustments. For example, Volkov et al. (1967), Bumett and Schumm (1983), and Ouchi (1985) interpret irregularities in presentday river profiles as reflecting vertical crustal movement. Snow and Slingerland (1990) simulated nonlinear response of a simplified stream system to the influences of crustal tilting and domal uplift.

The mathematical model applied in this paper describes uniform, steady flow and sediment routing in a channel with erodable bed provided lateral inflow of sediments is not considered. The equation describing generalized flow for an isotropic medium in one independent dimension is:

$$
Q=-\gamma_{s} \cdot \kappa \cdot \frac{\partial y}{\partial x},
$$

where $Q$ is the vector flux, $y$ is elevation ( $\mathrm{m}$ ) above base level, $\gamma_{s}$ is density $\left(\mathrm{kg} / \mathrm{m}^{3}\right)$, $\mathrm{x}$ is the distance, and $\kappa$ is the erosional diffusivity $\left(\mathrm{m}^{2} / \mathrm{yr}\right)$. Application of the equation of continuity for transient behavior leads to the diffusion equation in its most common form:

$$
\frac{\partial y}{\partial t}=\kappa \cdot \frac{\partial^{2} y}{\partial x^{2}} .
$$

For a terrain with a continuous, time independent uplift source, it may be expected that

$$
\frac{\partial y}{\partial t}=\kappa \cdot \frac{\partial^{2} y}{\partial x^{2}}+V_{(x)},
$$

where $t$ denotes time (in years), and $V_{(x)}$ is the uplift rate (m/year) at $\mathrm{x}$.

The model equation is solved numerically by an explicit finite-difference solution. A single modeled stream reach, $80 \mathrm{~km}$ in length, is used in this study to simulate a longitudinal profile subjected to successive uplifting at certain positions of the reach. The initial profile is modeled by an exponential function,

$$
y=y_{0} e^{\mathrm{ax}}
$$

where $y_{0}$ and a are constants. The uplifting component, $V_{(x)}$, is assigned by a step function in which $V_{x<x 0}=0$ and $V_{x>x 0}=0.1$. The step function is shifted downstream every thousand years of modeled time. The result is shown in Fig. 3. The uplifted profiles commonly have a gentler gradient in the upper reach and a steeper gradient in the lower reach than that of the initial profile. In contrast to the initial profile, which is assumed to be in equilibrium and is fitted by an exponential function, the uplifted one can be fitted piecewise by different functions. The upstream reach of the final modeled profile at the uplifted segment can be fitted by a linear function, while the downstream reach is better fitted by a steeper exponential function. Similar observations have been made by a flume experiment fitted by a flexible base to mimic uplift and subsidence (Ouchi 1985). Both braided channel and meandering channel adjusted to uplift by changes in their channel pattern. The braided channel aggraded both upstream and down- 


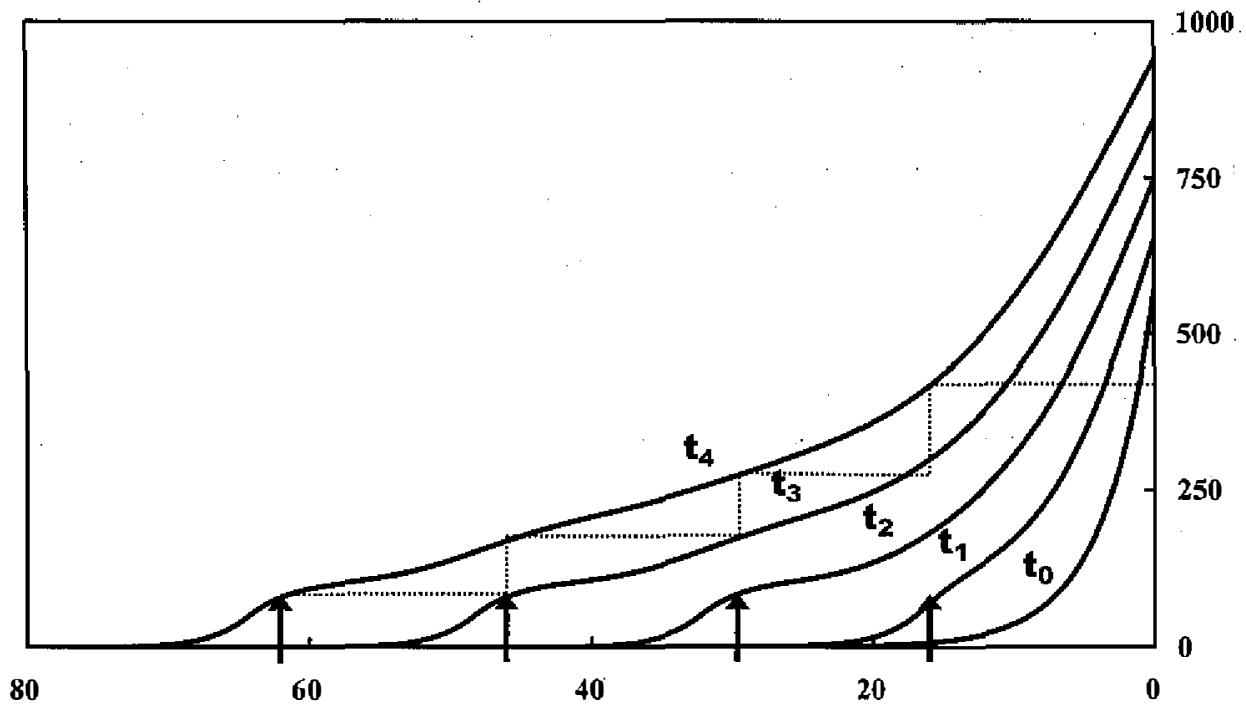

\section{Distance from river head ( $\mathrm{km}$ )}

Fig. 3. The modeled longitudinal profiles subjected to a successive uplift. $t_{0}$ denotes the initial profile, $t_{f}, t_{2}, t_{3}$ and $t_{4}$ denote the uplifted profiles subjected to a step function (broken line) in a time sequence. Arrows point to the uplifted position.

stream of the upwarp. The meandering channel increased its sinuosity downstream of the upwarp, while ponding occurred upstream. The numerical model showed that the zone of channel incision widened and the point of maximum channel-elevation increase (the net effect of uplift and incision) shifted upstream through time (Snow and Slingerland 1990).

The stream-gradient index (SL index) has been commonly used to highlight gradient change of a stream's longitudinal profile. It is believed to reflect stream power or competence and is simply the product of the channel slope at a point and channel length measured along the longest stream above the point where the calculation is made (Hack 1973). Usually it is very sensitive to changes in channel slope, and is applied to evaluate relationships between possible tectonic activity, rock resistance, and topography (Keller and Pinter 1996). In practice, the channel slope is averaged over a segment of the reach in order to smooth out local variations. Segment length is controlled by a relief of 30 meters in this study, and thus the upstream segment is shorter and the downstream segment longer. Therefore, positioning accuracy is worse in the downstream reach than in the upstream reach. The SL index curves of the initial stream profile and the final modeled profile are shown in Fig. 4. Assuming no lithologic variation and no lateral inflow of sediments, the profiles were simulated through four successive uplifting events. Peaks of the SL index curve actually indicate the position of relative uplift. Also, the more recent the tectonic event, the higher the SL index. Just as Snow and Slingerland (1990) predicted, over time, the SL index peak of the less active uplifts becomes lower and broader upstream. 


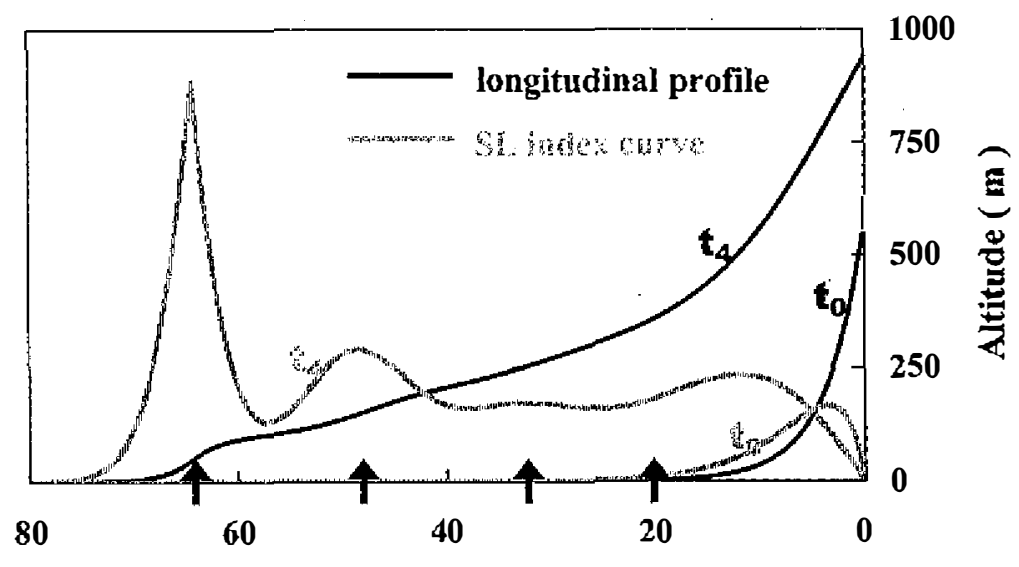

Distance from river head $(\mathrm{km})$

Fig. 4. The modeled longitudinal profiles subjected to a successive uplift and their SL index curves. $t_{0}$ denotes the initial profile and $t_{4}$, the final profile after four successive uplifting. Peaks of the SL index curve depict the uplifted position.

\section{THE STREAM GRADIENT CHANGE}

The behavior of a river profile adjusting to tectonic uplift can be applied to explain the stream gradient change of the three rivers studied during the period 1904 to 1985. Overlay of the above-mentioned two versions of topographic map by evaluating the match of coastal lines is generally successful. Although they may not possess the same level of accuracy, the comparison is also valid if a statistical test is performed. At first glance, there have been some distinct changes in the drainage pattern of the three rivers over the past 80 years (Fig. 5). The incised meanders have more or less shifted downstream in the middle reach. The alluvial channels in the lower reach have changed their courses laterally on the coastal plains and portions of channels have been confined by man-made constructions. Since the rivers run across the active folding and thrusting belt, the longitudinal profile of the three rivers in the lower reach of about $80 \mathrm{~km}$ in length is considered more tectonically controlled. The following is a statistical test performed to verify gradient change for each segment of longitudinal profile bounded by faults. At the beginning of the test, we tentatively divided the Wu River and the Tzoshui River into five segments by four north-south trending faults, namely, the Shuilikeng fault, the Shuangtung fault, the Chelungpu fault, and the Changhwa fault. The Tachia River can be also subdivided into five segments by four faults, namely, the Shuangtung fault, the Chelungpu fault, the Tungtzechiao fault and the Changhwa fault. The profile of each segment is best fitted by either an exponential function or a linear function with a significant level of at least higher than $96 \%$ (Fig. 6). Segments of longitudinal profile may be merged into one for each individual river respectively in terms of the goodness of fit of a regression function. For example, the Tachia River is regressed with a linear function for the entire reach 


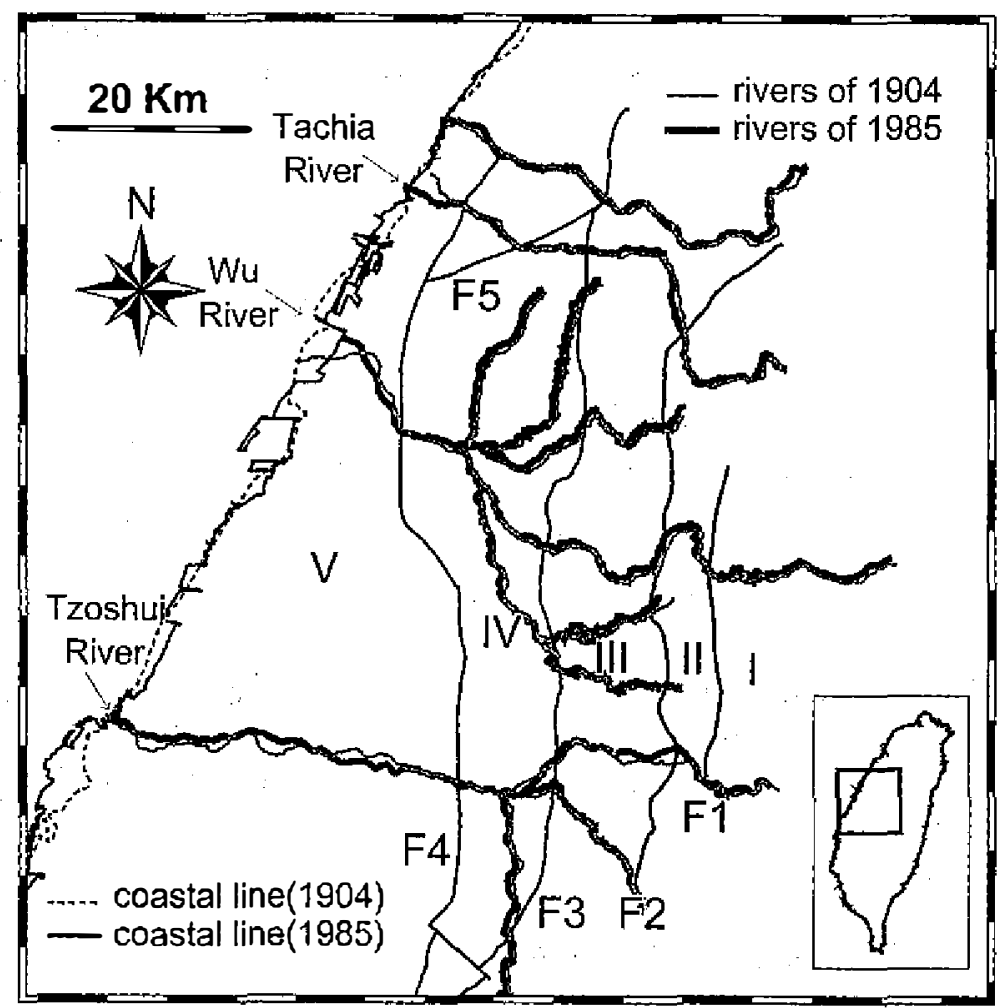

Stream gradient change from 1904 to 1985

Fig. 5. Overlay of coastal lines and rivers digitized from the 1904 Taiwan Bautu and the 1985 topographic map. The roman numerals denote the segments of the rivers. Rectangular frames denote the area of channel pattem analysis: F1: Shuilkeng fault. F2: Shuangtung fault. F3: Chelungpu fault. F4: Changhwa fault. F5: Tungtzechia fault.

studied. The lowest reach of the Wu river, as suggested by regression analysis, is not further segmented by the Changhwa fault. As a consequence, segmentation of the longitudinal profile for the three rivers can be further discussed in terms of tectonic implication. To be statistically valid in comparing the stream gradient of the same segment of longitudinal profile measured from the two versions of topographic map, it is necessary to take into consideration the Student $t$ test for parallelism for the regression lines. The null hypothesis for a comparison of slopes in the segment $i$ is given by

$$
H_{0}: \beta_{i, 1904}=\beta_{i, 1985}
$$

If the null hypothesis is rejected, the slope of the regression lines is not equal and the stream gradient of the segment has changed during the period 1904 to 1985 . Table 1 summarizes the test statistics for all segments of the three rivers. 
(a) The Tachia River

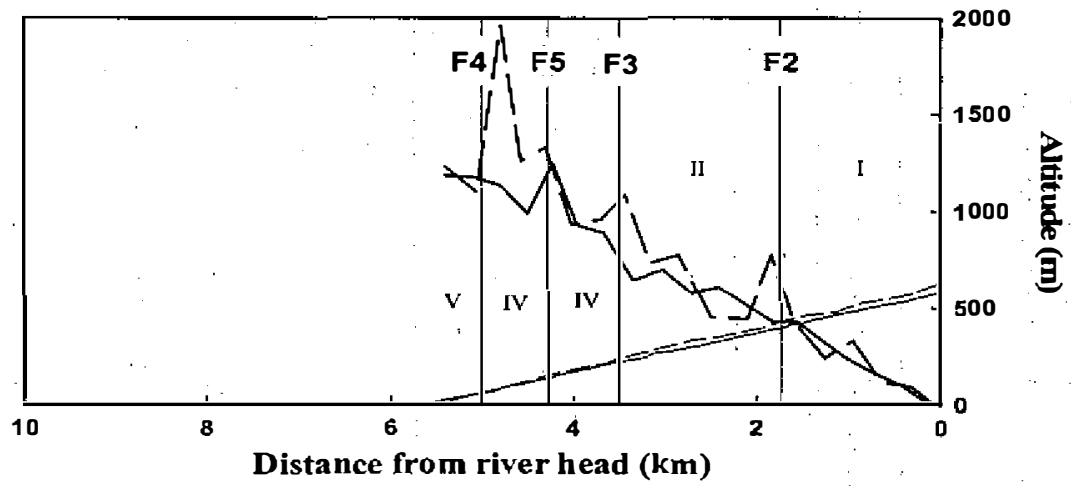

(b) The Wu River

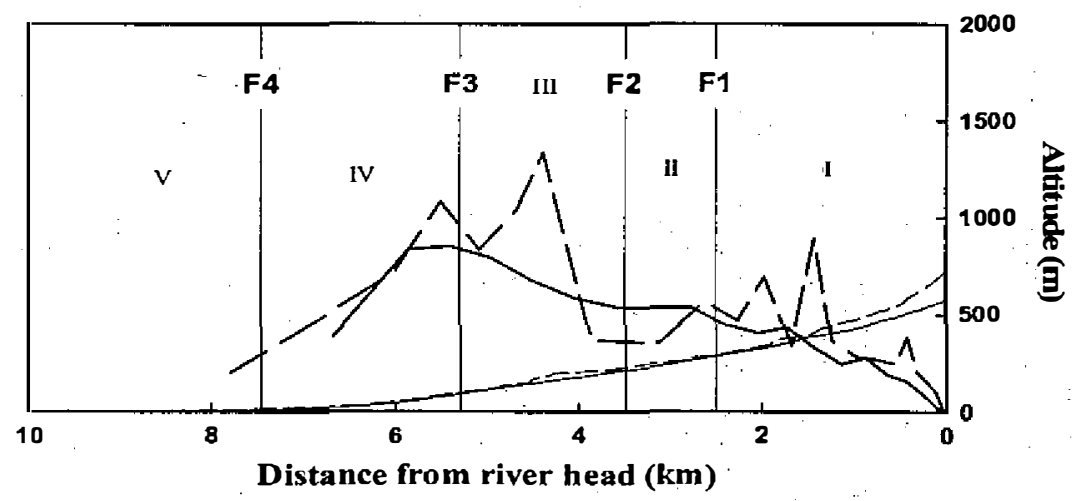

(c) The Tzoshui River

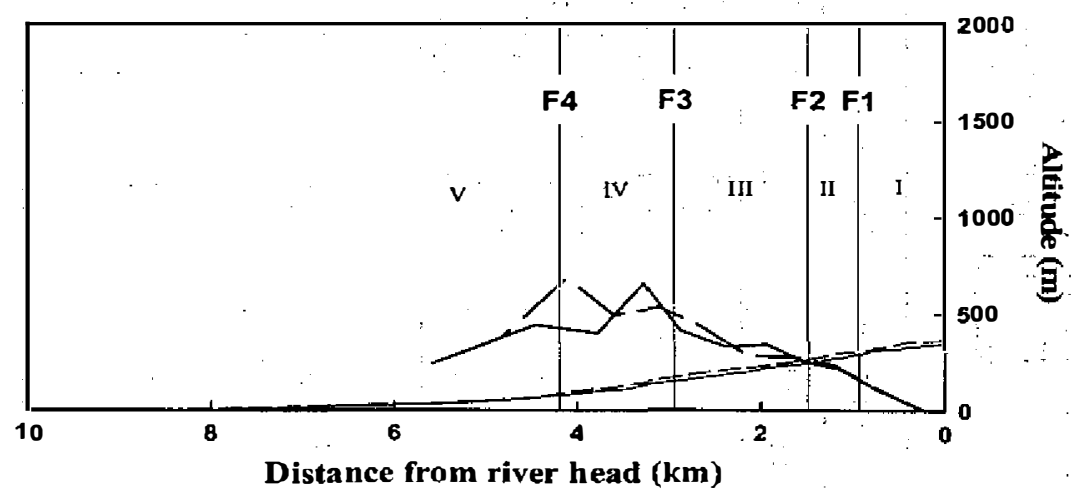

Fig. 6. Longitudinal profiles of three rivers digitized from the 1904 Taiwan Bautu and the 1985 topography map and their SL index curves. F1 F5 are active faults explained in Fig. 5. 
Table 1. Student $t$ test for gradient change of segments of longitudinal profiles between maps of 1904 and 1985 . The null hypothesis is given by $H_{0}: \beta_{i, 1904}=\beta_{i, 1985}$. Asterisks denote that the null hypothesis is rejected.

\begin{tabular}{|c|c|c|c|c|c|c|c|}
\hline Name & Segment & No. Data Points & Regression Function & $r^{2}$ & Test statistics & Gradient change & Comment \\
\hline Ta-Chia River & All & $\begin{array}{l}1715 \\
276 \\
\end{array}$ & $\begin{array}{l}(1904) y=-1.103 \times 10^{-2} x+617.13 \\
(1985) y=-1.029 \times 10^{-2} x+577.92\end{array}$ & $\begin{array}{l}0.999 \\
0.999 \\
\end{array}$ & $30.86^{*}$ & $-0: 745 \times 10^{-3}$ & $\begin{array}{c}\text { Significantly } \\
\text { decrease }\end{array}$ \\
\hline \multirow{4}{*}{ Wu River } & I & $\begin{array}{l}299 \\
211\end{array}$ & $\begin{array}{l}(1904) \log (y)=-3.436 \times 10^{-5} x+6.52 \\
(1985) \log (y)=-2.763 \times 10^{-5} x+6.349\end{array}$ & $\begin{array}{l}0.995 \\
0.998\end{array}$ & $36.26^{*}$ & $-0.673 \times 10^{-5}$ & $\begin{array}{l}\text { Significantly } \\
\text { decrease }\end{array}$ \\
\hline & II & $\begin{array}{c}254 \\
78\end{array}$ & $\begin{array}{l}(1904) y=-5.963 \times 10^{-3} x+436.92 \\
(1985) y=-7.885 \times 10^{-3} x+482.90\end{array}$ & $\begin{array}{l}0.960 \\
0.995 \\
\end{array}$ & $13.21^{*}$ & $+1.922 \times 10^{-3}$ & $\begin{array}{l}\text { Significantly } \\
\text { increase }\end{array}$ \\
\hline & III & $\begin{array}{l}273 \\
114 \\
\end{array}$ & $\begin{array}{l}(1904) y=-7.652 \times 10^{-3} x+505.09 \\
(1985) y=-6.647 \times 10^{-3} x+444.0\end{array}$ & $\begin{array}{l}0.952 \\
0.999 \\
\end{array}$ & $6.31^{*}$ & $-1.005 \times 10^{-3}$ & $\begin{array}{c}\text { Significantly } \\
\text { decrease }\end{array}$ \\
\hline & IV & $\begin{array}{l}240 \\
112 \\
\end{array}$ & $\begin{array}{l}(1904) \log (y)=-8.955 \times 10^{-5} x+9.312 \\
(1985) \log (y)=-11.470 \times 10^{-5} x+10.649\end{array}$ & $\begin{array}{l}0.990 \\
0.998 \\
\end{array}$ & 0.512 & $+2.515 \times 10^{-5}$ & $\begin{array}{c}\text { Non-significantly } \\
\text { increase }\end{array}$ \\
\hline \multirow{5}{*}{$\begin{array}{l}\text { Tzo-Shui } \\
\text { River }\end{array}$} & I & - & - & - . & - & - & Not compared \\
\hline & II & $\begin{array}{l}41 \\
23 \\
\end{array}$ & $\begin{array}{l}(1904) y=-8.474 \times 10^{-3} x+392.29 \\
(1985) y=-8.557 \times 10^{-3} x+371.32\end{array}$ & $\begin{array}{l}0.983 \\
0.993 \\
\end{array}$ & 0.34 & $+0.083 \times 10^{-3}$ & $\begin{array}{c}\text { Non-significantly } \\
\text { increase }\end{array}$ \\
\hline & III & $\begin{array}{l}150 \\
73\end{array}$ & $\begin{array}{l}(1904) y=-6.146 \times 10^{-3} x+352.71 \\
(1985) y=-6.767 \times 10^{-3} x+346.57\end{array}$ & $\begin{array}{l}0.996 \\
0.999 \\
\end{array}$ & $10.6^{*}$ & $+0.621 \times 10^{-3}$ & $\begin{array}{c}\text { Significantly } \\
\text { increase }\end{array}$ \\
\hline & IV & $\begin{array}{c}166 \\
64\end{array}$ & $\begin{array}{l}(1904) \log (y)=-5.856 \times 10^{-5} x+6.903 \\
(1985) \log (y)=-5.510 \times 10^{-5} x+6.644\end{array}$ & $\begin{array}{l}0.980 \\
0.991\end{array}$ & $2.82^{*}$ & $-0.346 \times 10^{-5}$ & $\begin{array}{l}\text { Significantly } \\
\text { decrease }\end{array}$ \\
\hline & V & $\begin{array}{l}239 \\
114\end{array}$ & $\begin{array}{l}(1904) \log (y)=-5.129 \times 10^{-5} x+6.452 \\
(1985) \log (y)=-6.338 \times 10^{-5} x+6.962\end{array}$ & $\begin{array}{l}0.991 \\
0.997\end{array}$ & $23.91^{*}$ & $+1.209 \times 10^{-5}$ & $\begin{array}{l}\text { Significantly } \\
\text { increase }\end{array}$ \\
\hline
\end{tabular}


The modeled longitudinal profile subjected to tectonic uplift has shown that the stream gradient decreases in the upper reach and increases in the lower reach of the longitudinal profile at the uplifted position. The modeled profile has been exaggerated in scale to highlight topographic response to tectonic movement. The longitudinal profile of natural rivers has a mild response to tectonic upwarping by changing stream gradients and/or drainage patterns (Ouchi 1985; Snow and Slingerland 1990). Considering the stream gradient change reflected in each segment of longitudinal profiles over the past 80 years, the Wu River is the most dynamic one among the three rivers. The stream gradient of the Wu River has changed significantly from segment I through segment III. It implies that the Shuilikeng fault and Chelungpu fault have been actively thrusting upward to induce a 13\%-32\% stream gradient change. The Tzoshui river shows less gradient change from segment III through segment $\mathrm{V}$. It indicates, however, a rather active upwarping at the Changhwa fault with a $24 \%$ change in stream gradient change. The stream gradient of the Tachia River has become gentler in the entire reach studied due to degrading process of the river and does not show any evidence of fault activity.

\section{THE SL INDEX}

The sensitivity of the SL index to changes in channel slope, as illustrated in Fig. 6, may possibly be related to tectonic activity or rock resistance. In landscape evolution, the adjustment of stream profiles to rock resistance is assumed to occur fairly quickly (Keller and Pinter 1996). Therefore, the SL index is used to identify recent tectonic activity by looking for anomalously high index values for a particular rock type. An area of high SL indices on soft rock may indicate recent tectonic activity. The SL index curves of the Tachia River for both map versions display a common upslope trend, with major peaks depicting the fault trace as well as the lithologic boundary (Fig. 6a). Since the Tachia river has braided channels below segment II, high SL index values on the 1904 map indicate the relative activity of the Shuangtung, Chelungpu, Changhwa and Tungtzechia faults. The Shuangtung fault also marks the lithologic boundary between the Pliocene shaly sequence and the Pleistocene Conglomerate. The 1985 SL index curve is much smoother than that for 1904, except for a high SL index anomaly on the Tungtzechia fault, indicating that the Tachia River has been in the process of gradation for the past 80 years. This implies that the Tungtzechia fault has remained active only since the surface rupture occurred during the 1935 earthquake. Of the three rivers, the Wu River shows the greatest change in the SL index curves between the two versions of map. The major slopebreak (the knick point) in the upper reach of the longitudinal profile of the 1904 map had been smoothed out and was not evident on that of the 1985 map, while the major slope-break in the lower reach remains for both profiles (Fig. 6b). The high values in segment I may reflect lithologic variations in the Oligocene series of quartzose sandstone and argillite, dispersed by river grading. The peak value in segment III denotes rock resistance of the Pleistocene Toukoshan Conglomerate and is smoothed out by gradation. The sustained peak of the SL index between segments III and IV implies that the Chelungpu fault has been more active than other faults along the Wu River. As for the Tzoshui River, there is also a greater change in the $S L$ index curves of the lower reach. The major peak of the 1904 profile has shifted upstream 
approaching the trace of the Chelungpu fault in the longitudinal profile of the 1985 map (Fig. 6c). This again reflects the recent high activity of the Chelungpu fault along the Tzoshui river.

The regional scale contour map of SL index values shows a significant change in the western block of the Shuangtung fault over the past 80 years (Fig. 7). The first derivative of the SL index curve usually emphasizes the deflection point of longitudinal profile of a river, which may be more sensitive to tectonic activity than to rock variation in this region. According to the model analyzed in the previous section, the area with a positive derivative value indicates the area uplifted, while the area with a negative derivative value indicates the area subsided or unchanged. The zero-value may depict the deflection point of the upwarped profile. This indicates a noteworthy change in position of the zero-contour line of the first derivative SL index over the past 80 years (Fig. 8). The zero-contour line is roughly coincident with the trace of the Chelungpu fault and makes a sharp turn near the Tachia River on the map of the 1985 profile (Fig. 8b). This indicates that the crustal deformation front in this region has migrated westwards to the present position of the Chelungpu fault. It may also explain why surface ruptures, induced by the Chi-Chi earthquake, follow the trace of the Chelungpu fault in most cases and turn sharply along the Tachia River, because the Tachia River marks the margin of crustal deformation since 1904. The comparison between historical maps leads to the conclusion that crustal deformation is more evident in the block between the Tachia River and the Wu River than in the block between the Wu River and the Tzoshui River. This is in agreement with the net slip of the Chelungpu fault induced by the Chi-Chi earthquake (Fig.2).

\section{DISCUSSIONS}

The Chi-Chi earthquake caused many coseismic modifications of rivers in central Taiwan. A 7 to $8 \mathrm{~m}$ high waterfall was created immediately after the earthquake by the reverse fault scarp in the Tachia riverbed. However, many effects of active tectonics are neither so sudden nor so dramatic as such coseismic events. More typically, tectonic deformation of the earth's surface takes place slowly over thousands of years or longer. Although deformation is imperceptible to the human eye, it can be detected using sensitive scientific instruments. River systems are the next most sensitive tool, capable of adjusting to deformation over periods of decades to centuries.(Keeler and Pinter 1996). An alluvial river tends to maintain itself in such a state of dynamic equilibrium that any change in one variable in the system will cause changes in other variables in the system in order to reestablish equilibrium. Tectonic uplift or tilting of just a few tenths of a percent can change the pattern of a river, such as from meandering to braided (Berberian et al. 1992). Response of experiment channels to uplift across the channel has shown that channel cutting proceeds at the axis of deformation while a strongly braided pattern and frequent channel shifts occur upstream and downstream (Ouchi 1985). Similar phenomena have been noticed, for example, at the lower reaches of the Tachia River and Tzoshui River. A strongly braided channel pattern is observed either upstream or downstream from the trace of the Tungtzechia and Chelungpu faults (Fig. 9). The implication is that both alluvial rivers have been adjusting their channels to active faults.

The forms of rivers or streams and the processes occurring in those systems are described 
(a) SL index(1904)

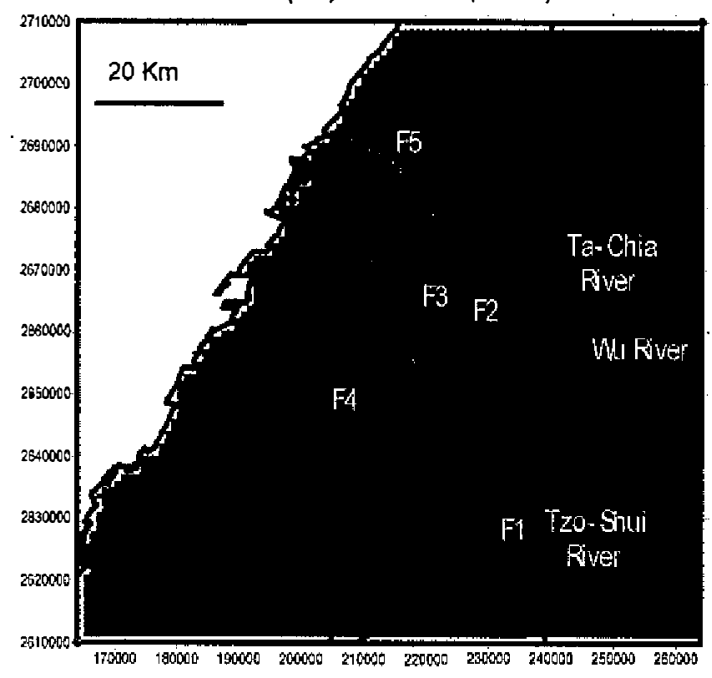

(b)SL index(1985)

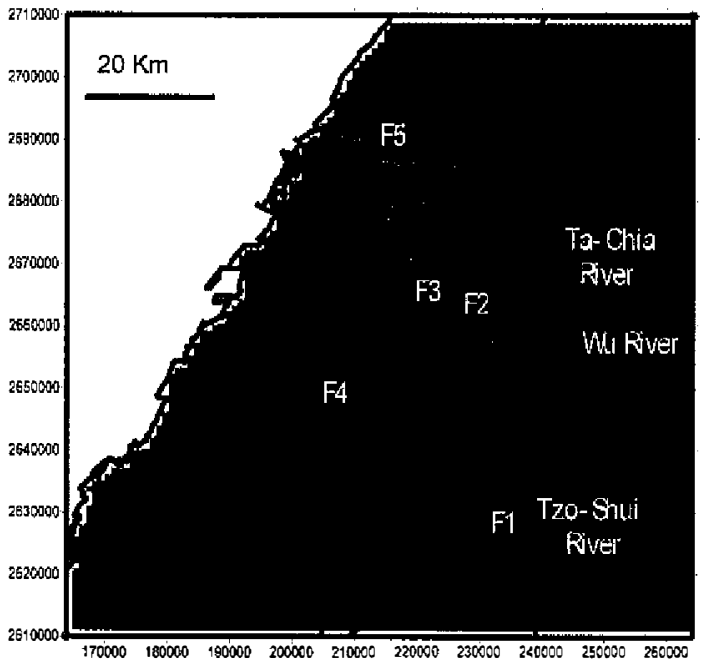

Fig. 7. Contour maps of the SL index calculated from the 1904 Taiwan Bautu and the 1985 topographic map. Red color denotes relatively high value, and blue color denotes relatively low value. Dots are control points of the $S L$ index value. Kriging is used for interpolation. F1 F5 are active faults explained in Fig.5.

(a) 1st derivative of SL index $(1904)$

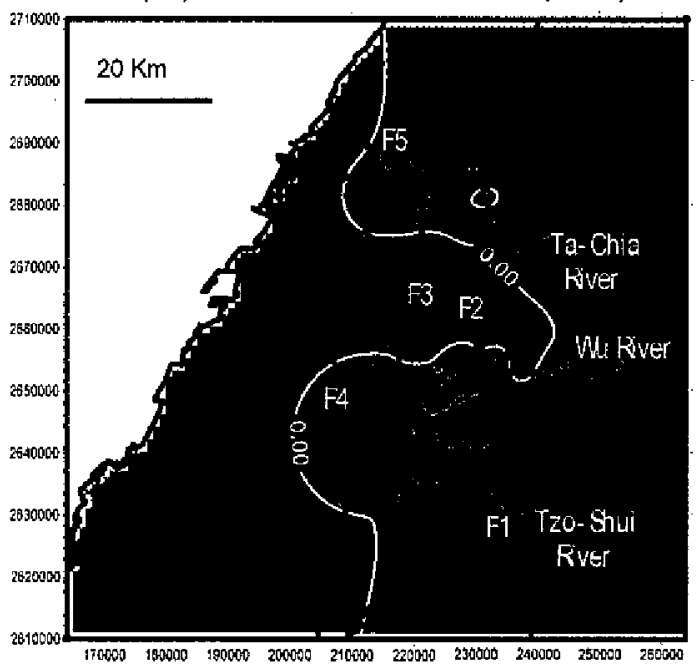

(b) 1st derivative of SL index(1985)

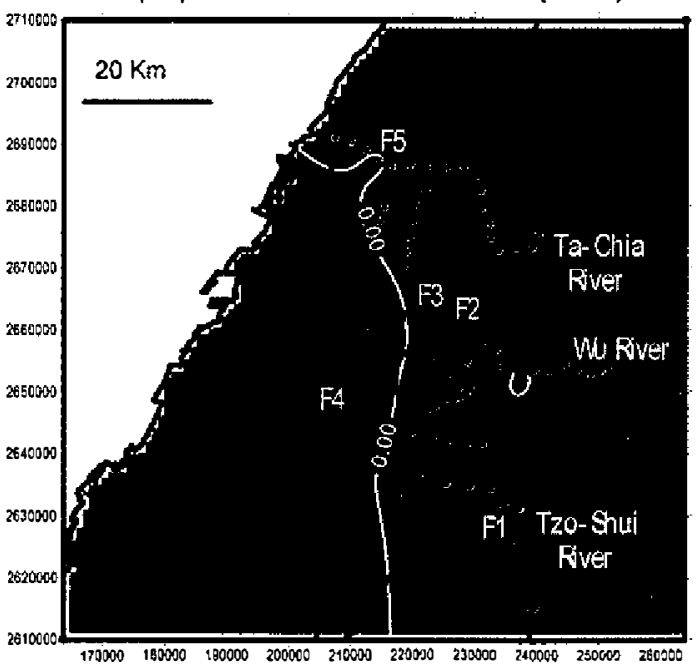

Fig. 8. Contour maps of 1st derivative of SL index derived from Fig. 7. Legend is explained in Fig. 7. The contour line of 0.00 denotes the deflection line of the upwarping surface. 

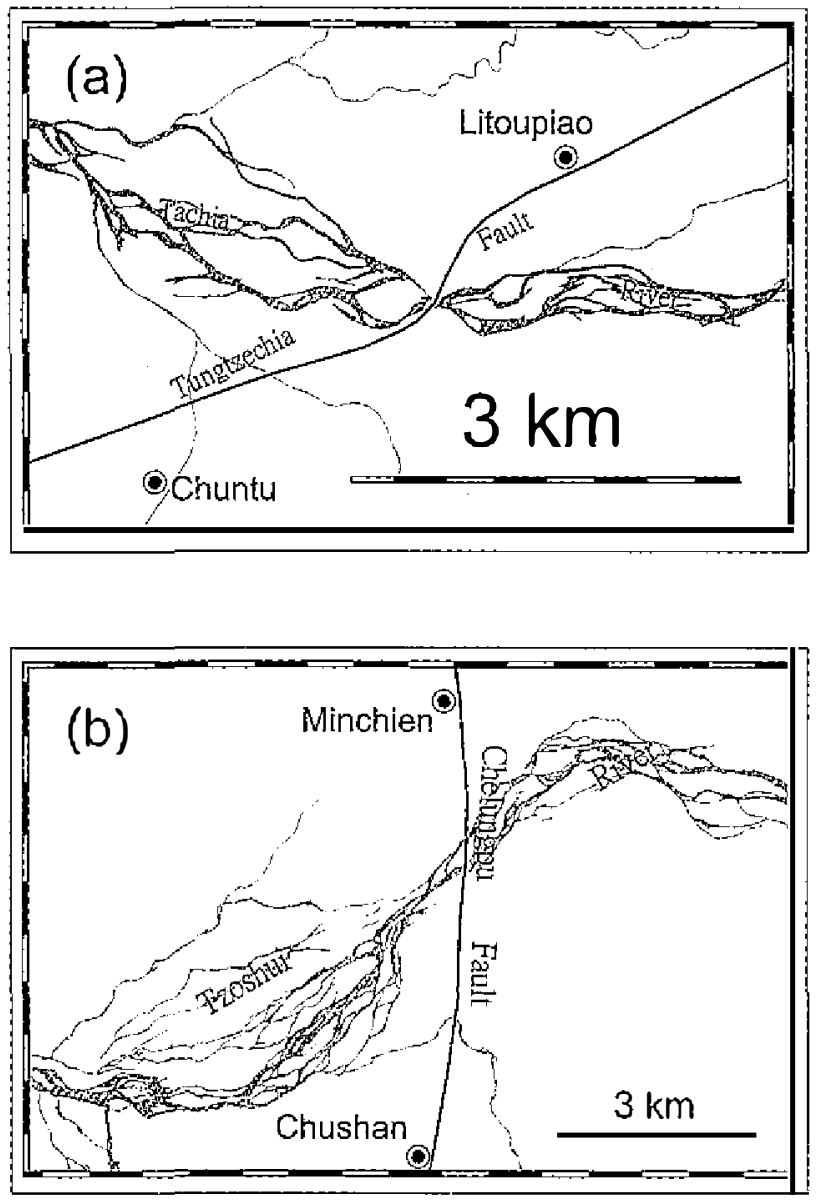

Fig. 9. Channel pattern and active faults (Location refers to Fig.5). (a) Strongly braided channels developed upstream and downstream reach of the Tungtzechia fault. The Tungtzechia fault is an earthquake fault formed in 1935, which has right-lateral displacement with a vertical scarp of about $0.6 \mathrm{~m}$ at riverbed (Chang 1994). (b) Strongly braided channels developed upstream and downstream reach of the Chelungpu fault. The Chelungpu fault is upthrusting toward west ( CGS 1999).

by a large number of parameters: channel width and depth, sediment load, channel slope and sinuosity, and many others. Each of these parameters may provide signs of tectonic activity. When more than one parameter is applied to a particular region, the results are more meaningful than those of any single analysis (Bull 1977 and 1978). A comprehensive study of stream gradient change, in terms of regression analysis, the SL index, and channel pattern, leads to the conclusion that during the past century, the Chelungpu fault has been the most active of the five faults discussed in this study. 
Although the accuracy of the maps studied requires further verification, there are a few reasons for taking the results of this comparison between two versions of maps into consideration. First, both versions of topographic map have the common original control point located at Futzeshan, near the small town of Puli in central Taiwan. They also have a common coordinate system in latitude and longitude. Second, the general match of coastal lines of the two maps indicates that both maps have an equivalent level of accuracy (Fig. 5). Third, the data quality of the coordinates of the river profiles is relatively good due to its ease of accessibility. Nevertheless, an accuracy assessment of historical maps needs to be done if crustal deformation is to be verified quantitatively.

\section{CONCLUDING REMARKS}

The Chi-Chi earthquake caused a permanent displacement along the Chelungpu fault in central Taiwan. This crustal deformation is not conformable to that monitored by the GPS Network during the period 1990 to 1995 (Fig. 2). On the other hand, the crustal deformation revealed by stream gradient change during the period 1904 to 1985 shows a good agreement with that induced by the Chi-Chi earthquake. This study thus demonstrates a potential tool in the research of earthquake prediction and seismic hazard assessment. Further detailed studies on the change of stream profile and channel pattern in history are encouraged.

Acknowledgements The authors thank Prof. John Suppe for his critical review of the draft. They are also greatly indebted to Y. T. Tan, K. C. King, C. C. Yang and D. S. Chen for digitizing the maps. The research was supported by the National Science Council under grant NSC 89-2119-M-017-001.

\section{REFERENCES}

Berberian, M., M. Qorashi, J. A. Jackson, K. Priestley, and T. Wallace, 1992: The Rud-barTarom earthquake of 20 June in NW Persia: preliminary field and seismological observations, and its tectonic significance. Bull Seism. Soc. Am., 82, 1726-1775.

Bull, W. B., 1977: Tectonic geomorphology of the Mojave Desert. U.S. Geological Survey Contract Report 14-08-001-G-394. Office of Earthquakes, Volcanoes and Engineering, Menlo Park, CA.

Bull, W. B., 1978: Geomorphic tectonic classes of the south front of the San Gabriel Mountains, Califomia, U.S. Geological Survey Contract Report 14-08-001-G-394. Office of Earthquakes, Volcanoes and Engineering, Menlo Park, CA.

Bumett, A. W., and S. A. Schumm, 1983: Alluvial-river response to neotectonic deformation in Louisiana and Mississippi. Science, 222, 49-50.

CGS, 1999: Report of geological investigation of the 921 Chi-Chi earthquake: Central Geological Survey, MOEA, ROC, 350 pages.(in Chinese)

Chang, H. C., 1994: Explanatory text of the geologic map of Taiwan, Scale 1:50000, Sheet 17, TACHIA: Central Geological Survey, MOEA, ROC, 63 pp. 
Chang, S. L., 1971: Subsurface geologic study of the Taichung basin. Petrol. Geol. Taiwan, 8, 21-45.

Cheng, S. N., Y. T. Yeh, W. C. Huang, M. T. Hsu, and T. C. Shin, 1999: Photo Album of ten Disastrous earthquakes in Taiwan, CWB-9-199-002-9. Central Weather Bureau and the Institute of Earth Sciences, Academia Sinica, ROC, 289 pp.

CPC, 1982a: The geological map of Taichung, scale 1:100,000. Published by Taiwan Petroleum Exploration Division, Chinese Petroleum Corporation, Taiwan, ROC

CPC, 1982b: The geological map of Chiayi, scale 1:100,000. Published by Taiwan Petroleum Exploration Division, Chinese Petroleum Corporation, Taiwan, ROC

Hack, J. T., 1973: Stream-profile analysis and stream-gradient index. U.S. Geol. Surv. Jour. Res., 1, 421-429.

Ho, C.S., 1988: An introduction to the geology of Taiwan: Explanatory text for the geologic map of Taiwan. Minist. Econ. Aff., Taipei, 2nd ed., 164pp.

Keller, E. A., and N. Pinter, 1996: Active Tectonics: earthquake, uplift, and landscape. Prentice Hall, New Jersey.

Ma, K. F., C. T. Lee, and Y. B. Tsai, 1999: The Chi-Chi, Taiwan earthquake: Large surface displacements on an inland thrust fault. EOS, 80, 604-605.

Ouchi, S., 1985: Response of alluvial rivers to slow active tectonic movement. Geol. Soc. Am. Bull., 96, 504-515.

Snow, R. S., and R. L. Slingerland, 1990: Stream profile adjustment to crustal warping: Nonlinear results from a simple model. J. Geol., 98, 699-708.

Suppe, J., 1981: Mechanics of mountain building and metamorphism in Taiwan. Mem. Geol. Soc. China, 4, 67-89.

Suppe, J., 1983: Geometry and kinematics of fault-bend folding. Am. J. Sci. 283, 684-721.

Tanner, W. F., 1971: The river profile. J. Geology, 79, 482-492.

Teng, L. S., 1987: Stratigraphy records of the late Cenozoic Penglai orogeny of Taiwan. Acta Geol. Taiwan, 25, 205-224.

Teng, L. S., 1990: Geotectonic evolution of late Cenozoic arc-continent collision in Taiwan. Tectonophysics, 183, 57-76.

Vlokov, N. G., I. L. Sokolovsky, and A. I. Subbotin, 1967: Effect of recent crustal movements on the shape of longitudinal profiles and water levels in rivers. Symposium on River Mechanics (Bern): Int Union Geodesy Geophys. Pub., 75, 105-116.

Yu, S. B. Y. S. Chen, and L. C. Kuo, 1997: Velocity field of GPS stations in Taiwan area. Tectonophysics, 274, 41-59. 